\title{
Reflexões sobre nomeações a cargos públicos no Brasil: a experiência de três secretarias entre 2011 e 2018
}

\author{
Nayara F. Macedo de Medeiros Albrecht ${ }^{1,2}$ (i)
}

DOI: $10.1590 / 0103-3352.2021 .36 .246012$

\section{Introdução ${ }^{3}$}

Historicamente, os estudos sobre burocracia se concentram na relação entre administração e política. Ainda que essa dicotomia tenha sido constantemente questionada pela literatura especializada (PACHECO, 2002; PRAÇA; FREITAS; HOEPERS, 2011; CAVALCANTE; LOTTA; OLIVEIRA, 2018), parte relevante das pesquisas associa a chamada "politização da burocracia" a práticas clientelistas ou distributivistas.

O próprio uso da palavra "politização" promove uma visão maniqueísta que separa a "técnica", associada ao mérito e à qualificação, da "política", relacionada à busca pelo poder e à troca de favores (ABERS; OLIVEIRA, 2015). Este artigo visa promover reflexões sobre o estudo da burocracia no Brasil, com foco nas dinâmicas das nomeações a cargos de alto escalão. Para tal propósito,

1 Pesquisadora Visitante da Universidade Federal de São Carlos (UFSCar), Departamento de Ciências Sociais do Centro de Educação e Ciências Humanas, São Carlos, SP, Brasil. E-mail: nayara.albrecht@ufscar.br

2 Para replicação dos dados: https://doi.org/10.7910/DVN/PVH5LL

3 Este artigo faz parte de pesquisa desenvolvida na Universidade Federal de São Carlos (UFSCar) com o apoio da Fundação de Amparo à Pesquisa do Estado de São Paulo (FAPESP) (Projeto nº 2019/19570-8) e a supervisão do professor Pedro Floriano Ribeiro, a quem presto meus agradecimentos. Aproveito para agradecer aos comentários dos/as pareceristas anônimos/as da revista, ao Instituto de Pesquisa Econômica Aplicada (IPEA) e à turma da disciplina que ministro na pós-graduação da UFSCar ("Tópicos em Políticas Públicas: Política, Burocracia e Grupos de Interesse") por suas contribuições. Reflexões preliminares foram apresentadas durante o $44^{\circ}$ Encontro da ANPOCS em 2020 e a edição virtual da IPSA-USP Summer School em 2021. Agradeço ainda a Vinícius Alves, Carol Corrêa e Glauco Peres pelos comentários e sugestões. Sou responsável por qualquer erro ou equívoco. 
o artigo alia uma revisão de literatura integrativa à análise exploratória do cenário brasileiro e à pesquisa aprofundada de três órgãos de assistência no período de 2011 a 2018. O objetivo principal é averiguar a compatibilidade entre as previsões teóricas concernentes às nomeações, os dados gerais e os três casos.

$\mathrm{O}$ artigo traz algumas inovações em relação às pesquisas anteriores. A revisão de literatura combina um mapeamento mais sistemático da literatura recente sobre burocracia com estudos sobre política de pressão. Os instrumentos analíticos das pesquisas sobre lobby contribuem para a identificação de novas ferramentas para superar desafios metodológicos relativos aos processos de nomeação. Ademais, as reflexões teóricas são aplicadas a um estudo longitudinal de três órgãos públicos em contraste com a natureza quantitativa da maioria das pesquisas empíricas nesse campo. Trata-se de um esforço importante em promover uma análise mais detida em relação à literatura prévia, o que contribui para o teste de mecanismos causais e a construção de hipóteses alternativas.

Ao conferir maior ênfase aos partidos, os trabalhos anteriores associam o conceito de politização à partidarização de modo a obscurecer outros tipos de atividade política. Em contraste, o estudo dos três casos confirma a importância de outros vínculos e o baixo impacto das filiações partidárias de modo a contribuir para a formulação de argumentos alternativos sobre o processo decisório. Além de propor uma nova opção de enquadramento para lidar com os padrões de nomeação, questiono a relação entre distribuição de cargos e presidencialismo de coalizão apontando ainda outros elementos que merecem análise mais detida nesse debate.

\section{Estado da arte da literatura: desafios e alternativas}

A literatura brasileira sobre nomeações a cargos burocráticos confere maior ênfase à "politização" da burocracia e aos dilemas presidenciais ao escolher dirigentes do Executivo Federal. Os trabalhos "clássicos" focavam nas relações entre burocratas e setor privado destacando as diferentes estratégias de nomeação que conviviam com as gramáticas clientelistas presentes no contexto brasileiro (GEDDES, 1994; NUNES, 1997; EVANS, 2004). Já os trabalhos mais recentes se concentram nas motivações relativas às nomeações aos cargos comissionados (os chamados cargos de "Direção e Assessoramento" 
- "DAS”), que se caracterizam pelo livre provimento. Nesse contexto, o termo "politização" se refere à nomeação decorrente de razões políticas (LOPEZ; PRAÇA, 2018) em contraste a outros fatores, que compreendem a qualificação técnica e os objetivos relacionados às políticas públicas.

Considerando o desenho institucional do sistema brasileiro, a alocação de cargos públicos é frequentemente citada como uma das estratégias adotadas pelo Executivo para manter o apoio de sua coalizão (MENEGUELLO, 1998; LOUREIRO; OLIVIERI; MARTES, 2010; BARBERIA; PRAÇA, 2014; GUIMARÃES; PERLIN; MAIA, 2019). Os estudos assumem que a composição de uma coalizão heterogênea impõe constrangimentos ao/à presidente devido à necessidade de acomodar interesses diversos, o que repercute na relação com o legislativo e no comando da burocracia (LAMEIRÃO, 2015). Nessa conjuntura, os cargos seriam usados como "moeda de troca" para garantir o apoio dos/as congressistas (LOUREIRO; OLIVIERI; MARTES, 2010).

A distribuição de cargos públicos seria, portanto, um elemento de barganha a ser negociado com os partidos, os quais indicariam indivíduos por diferentes objetivos: buscar apoio eleitoral de determinados segmentos; recompensar filiados/as que trabalharam voluntariamente pelo partido; fortalecer relações pessoais; ou ainda ter mais controle sobre as políticas públicas (KEMAHLIOĞLU, 2011; SCHERLIS, 2013; ABERS; OLIVEIRA, 2015). Nessa direção, utiliza-se o termo "patronagem" em referência às indicações partidárias na composição dos quadros burocráticos, o que vincularia o/a "cliente" (recebedor/a do benefício) ao/à "patrão" ou "patroa" (BEARFIELD, 2009; KOPECKÝ; MAIR, 2011).

Os trabalhos críticos sobre esse fenômeno dividem-se em duas perspectivas: uma que associa a patronagem a práticas clientelistas (KEMAHLIOĞLU, 2011) e outra que relaciona o conceito meramente à discricionariedade das nomeações (KOPECKÝ; MAIR, 2011). Predominante na produção da Ciência Política, a primeira associa a patronagem à alocação de postos públicos como forma de recompensa a membros do partido ou de barganha por apoio político, motivações associadas a benefícios particulares ou individualistas (O'DWYER, 2006; KEMAHLIOĞLU, 2011; LOPEZ; PRAÇA, 2015; ABRUCIO; LOUREIRO, 2018; BATISTA; LOPEZ, 2021). 
Por outro lado, outros/as autores/as relacionam o conceito à prerrogativa de indicar pessoas para compor quadros burocráticos evitando um julgamento de natureza normativa. Nesse sentido, a patronagem abrangeria outros motivos além da busca por apoio político, como o controle sobre as políticas públicas (KOPECKÝ; MAIR, 2011; LOPES; VIEIRA, 2020). Bearfield (2009) estabelece ainda quatro estilos diferentes de patronagem, os quais variam segundo os objetivos das indicações.

Tanto na literatura nacional quanto na estrangeira, as pesquisas sobre politização da burocracia conferem ênfase às motivações que permeiam as indicações partidárias, assim como aos fatores institucionais que condicionam tais escolhas (KEMAHLIOĞLU, 2011; PRAÇA; FREITAS; HOEPERS, 2011; LOPEZ; BUGARIN; BUGARIN, 2013; BARBERIA; PRAÇA, 2014). Com foco nas instituições formais, tais estudos estabelecem os partidos políticos como atores racionais que exercem protagonismo nesse processo.

No que tange à literatura internacional, os elementos centrais são as características das organizações partidárias e dos sistemas políticos, sobretudo aqueles que incidem nos níveis de competição intrapartidária (O’DWYER, 2006; KEMAHLIOĞLU, 2011; SCHERLIS, 2013). Já as análises sobre o contexto brasileiro se concentram no papel dos partidos políticos em função do arcabouço institucional do presidencialismo de coalizão (BARBERIA; PRAÇA, 2014; BORGES; COÊLHO, 2015; BERSCH; PRAÇA; TAYLOR, 2017; LOPEZ; SILVA, 2019).

As motivações são usualmente divididas entre razões políticas e motivos relacionados ao andamento das políticas públicas e ao conhecimento técnico. Entretanto, devido à natureza multicausal do fenômeno, é inviável separar as motivações que incidem no processo de nomeação, uma vez que diversos fatores se entrelaçam (LOPEZ; PRAÇA, 2018). Atuação política e qualificação técnica não são mutuamente excludentes, pois o livre provimento pode resultar na atração de novos quadros qualificados (ABERS; OLIVEIRA, 2015). Todavia, as pesquisas empíricas persistem em classificar as nomeações com base na ideia de politização, associada predominantemente à partidarização devido à utilização da "filiação partidária" como proxy.

Assim, os partidos políticos são os atores por excelência no debate sobre politização da burocracia. Praça, Freitas e Hoepers (2011) analisam as indicações partidárias e a força dos membros da base no Congresso. Bersch, Praça 
e Taylor (2017) utilizam a quantidade de filiados/as ocupando postos de direção para estimar a autonomia dos órgãos governamentais. Lopez e Silva (2019) analisam os dados sobre filiações partidárias de funcionários/as públicos/as de 1999 a 2018. Alguns estudos versam sobre movimentos sociais e suas interlocuções com a burocracia pública (LOSEKANN, 2012; ABERS; OLIVEIRA, 2015; RECH, 2020). Uma quantidade muito menor trata dos grupos de interesse (LOPES; VIEIRA, 2020).

Ainda que a literatura mencione recorrentemente outras relações com os partidos (além das filiações) e os vínculos não partidários (LAMEIRÃO; D’ARAÚJO, 2011; LOPEZ; BUGARIN; BUGARIN, 2015; LOPEZ; SILVA, 2019), poucos trabalhos apresentam uma análise mais arqueológica dos órgãos. Loureiro, Olivieri e Martes (2010) chegam a mencionar os grupos de interesse, mas não aprofundam os impactos dos grupos nas nomeações, nem as relações entre eles e os partidos ou burocratas.

Mesmo os estudos específicos sobre lobby carecem de maior ênfase nas nomeações, uma vez que se concentram na aprovação ou na rejeição de políticas específicas e nas questões relativas à regulamentação. Ademais, nesse campo analítico, o parlamento é a arena principal (MANCUSO, 2004; SANTOS, 2007). Apesar da ênfase conferida ao Poder Legislativo, a ocupação de cargos públicos do Poder Executivo pode ser um recurso relevante para os grupos de interesse, considerando a influência direta de burocratas de alto escalão sobre decisões públicas.

Nessa perspectiva, Andréa Gozetto e Wagner Mancuso (2018) mencionam a ocupação de cargos como um potencial alvo das atividades de defesa de interesses. Segundo os autores (2018, p. 55):

o trabalho de defesa de interesses pode remontar ao momento em que os decisores estão sendo escolhidos. Nesse momento, o objetivo é favorecer a escolha de decisores alinhados aos interesses defendidos, bem como desfavorecer a escolha de decisores menos afinados com os segmentos representados. A tentativa de influenciar a escolha dos decisores pode ocorrer em duas circunstâncias. A primeira é a definição dos indivíduos que ocuparão cargos com poder de decisão. A segunda é a escolha, entre os ocupantes desses 
cargos, daqueles indivíduos que efetivamente tomarão decisões referentes ao interesse defendido pelo lobista (grifos meus).

Segundo Gozetto e Mancuso (2018), os grupos podem atuar perante quem escolhe os nomes direta ou indiretamente, ou seja, o ministro, os partidos ou mesmo a mídia. Entretanto, ainda faltam pesquisas empíricas sobre o papel do lobby na definição de indivíduos para ocupar cargos (LOPES; VIEIRA, 2020), principalmente quando essa atuação ocorre por intermédio de partidos políticos ou parlamentares específicos. A falta de estudos provavelmente decorre das dificuldades metodológicas em analisar o impacto dos grupos de interesse nas nomeações. A própria literatura sobre lobby pode, porém, contribuir para lidar com essas dificuldades.

Em relação às tentativas de mensurar a "influência", por exemplo, as pesquisas sobre lobby recorrem geralmente a dois indicadores: as impressões, cujas principais fontes são os lobistas, os tomadores de decisão e os observadores externos; e os resultados, que consistem na avaliação de sua congruência em relação às demandas dos grupos (GOZETTO; MANCUSO, 2018). Assim, o "sucesso" - entendido como a convergência entre o teor da decisão e a posição defendida pelo/a lobista - poderia ser utilizado como uma proxy para estimar a influência dos grupos no processo de nomeação, ainda que seja uma medida imperfeita. Nesse sentido, averiguar os resultados das políticas e sua convergência ou divergência com as agendas dos grupos de pressão é um caminho para encontrar evidências acerca da relação entre grupos e burocratas.

É evidente que a constatação do sucesso do lobby não é o mesmo que medir sua influência, visto que o resultado pode ter outros fatores como causa. A influência pressupõe causalidade além da convergência (GOZETTO; MANCUSO, 2018). O caráter multidimensional do fenômeno estudado (nomeações) traz obstáculos adicionais à verificação de relações causais. As escolhas incluem um componente subjetivo e de difícil mensuração: as motivações dos agentes. Desse modo, a literatura brasileira utiliza dois fatores para verificar a influência dos partidos políticos no processo de nomeações: a vinculação formal dos/as nomeados/as à carreira pública, cujo ingresso ocorre mediante concurso, e a filiação partidária. Os estudos concentram-se na ocupação de cargos DAS devido ao caráter discricionário das nomeações e ao papel de 
gestão na estrutura burocrática (PRAÇA; FREITAS; HOEPERS, 2011; LOPEZ; BUGARIN; BUGARIN, 2013; LOPEZ; PRAÇA, 2018; LOPEZ; SILVA, 2019).

A filiação partidária é relacionada a uma indicação considerada "política” enquanto a vinculação ao serviço público e demais características (nível de instrução, entre outras) são tidas como elementos de natureza "técnica” (BARBERIA; PRAÇA, 2014; LOPEZ, 2015; BORGES; COÊLHO, 2015). Nota-se que a ênfase nas filiações se justifica na premissa de que os cargos são ferramentas de barganha do/a presidente em relação à coalizão. Dessa forma, a vinculação partidária de funcionários/as serviria para identificar as estratégias presidenciais para equilibrar os interesses partidários face ao contexto institucional do presidencialismo brasileiro. No entanto, ao passo que a literatura trata da lógica político-partidária como se fosse possível separá-la da busca por qualificação ou expertise, ambas consistem em elementos difíceis de observar separadamente.

Segundo informações extraídas de entrevistas (LOPEZ; PRAÇA, 2015), os elementos que justificam as nomeações aparecem juntos (formação acadêmica, redes, etc.). Além disso, a filiação partidária não é o único aspecto da politização, nem o critério mais relevante (LOPEZ; PRAÇA, 2018). A fronteira entre técnica e política é, portanto, turva, tendo em vista que as motivações para as nomeações não são distinguíveis (LOPEZ; SILVA, 2019) e tampouco mutuamente excludentes.

Estudos mais recentes (LOPEZ; PRAÇA, 2018; LOPEZ; SILVA, 2019) destacam a insuficiência da filiação partidária como proxy de politização devido à existência de outros tipos de redes e vínculos partidários. No entanto, as pesquisas falham em fornecer uma análise mais detida de informações que ofereçam pistas sobre a atuação de outros agentes além dos partidos. A pesquisa aprofundada dos três casos aqui apresentados visa contribuir para apontar caminhos de investigação. Ao se debruçar sobre três órgãos de forma mais intensiva, a pesquisa fornece pistas sobre possibilidades de analisar os pormenores dos processos decisórios referentes à nomeação a postos burocráticos.

\section{Métodos e dados}

Além da revisão integrativa de literatura, a metodologia da pesquisa compreendeu uma análise exploratória de dados e estudos de três casos em 
perspectiva comparada. O artigo se concentra na relação entre as reflexões teóricas e os dados. O levantamento da literatura foi feito com base em buscadores e indexadores de conteúdo de Ciências Sociais com os filtros originais "burocracia" e "cargos", assim como as expressões equivalentes em inglês e espanhol. Os materiais da seleção final foram agrupados segundo o tratamento conferido aos conceitos aqui discutidos, sobretudo "politização", "partidarização" e "patronagem". Consistem em artigos, livros e teses publicados entre 1980 e 2020.

Da revisão de literatura, observou-se que o debate brasileiro se concentrou na construção clientelista do Estado e na nomeação como ferramenta do presidencialismo de coalizão, com predominância do institucionalismo formal como paradigma de análise. Nesse sentido, a indicação a cargos de alto escalão na burocracia é vista como uma estratégia do chefe do Poder Executivo para angariar apoio político da coalizão face ao ambiente institucional do sistema político brasileiro. As pesquisas se concentram na atuação dos partidos, mensurada mediante a filiação partidária dos/as ocupantes do cargo. Nota-se, portanto, uma forte influência dos estudos presidenciais dos Estados Unidos e dos trabalhos sobre partidos na Europa.

No que tange à estatística descritiva, averiguei dados disponíveis nas bases do Painel Estatístico Pessoal (PEP) 4 e do IPEA (Atlas do Estado Brasileiro e base original que congrega dados do serviço público e do Tribunal Eleitoral) ${ }^{5}$. Ademais, foram analisados decretos e demais documentos que estabelecem as regras das nomeações desde a criação dos cargos DAS até 2020. Em complementação, examinei qualitativamente a nomeação do cargo mais alto em secretarias de diferentes órgãos do governo federal de modo a averiguar em que medida os casos convergem com as predições teóricas e as estatísticas gerais. Assim, o estudo qualitativo buscou aprofundar as questões extraídas da discussão teórica e da estatística descritiva.

Para esse propósito, foram escolhidas três secretarias nacionais de diferentes pastas: a Secretaria de Direitos Autorais e Propriedade Intelectual (SDAPI), da pasta de cultura; a Secretaria de Desenvolvimento Tecnológico e Inovação (SETEC), da pasta de ciência e tecnologia; e a Secretaria de Defesa

4 Disponível em: https://dados.gov.br/aplicativo/painel-estatistico-pessoal-pep. Acesso em: out. 2020.

5 Disponivel em: https://www.ipea.gov.br/atlasestado/filtros-series. Acesso em: out. 2020. Agradeço mais uma vez ao órgão pela disponibilização da base de dados original. Todas as informações potencialmente sensíveis foram eliminadas, assim como os nomes dos/as funcionários/as não são divulgados no decorrer do texto, embora sejam dados de natureza pública. 
Agropecuária (SDA), da pasta de agricultura. A escolha dos casos se justificou devido às diferenças dos órgãos em relação aos seguintes aspectos: partidarização, conforme índice elaborado por Borges e Coêlho (2015)6; saliência da pasta (ZUCCO JR.; BATISTA; POWER, 2019); e estruturas organizacionais (tamanho e orçamento).

De acordo com o índice elaborado por Borges e Coêlho (2015), as pastas da agricultura e da cultura seriam mais partidarizadas em relação à área de Ciência e Tecnologia. As três pastas possuem níveis diferentes de saliência segundo Zucco Jr., Batista e Power (2019), assim como diferem em tamanho (número de secretarias e de cargos) e orçamento. Por outro lado, as três pastas formulam e implementam políticas de mesmo tipo segundo a classificação de Batista e Lopez (2021), i.e. políticas regulatórias - o que permite a reprodução de certo controle para identificar quais outros fatores incidiriam sobre os processos de nomeação ${ }^{7}$. Ao passo que estudos prévios ressaltam que órgãos responsáveis por políticas regulatórias são mais permeáveis a grupos, as três secretarias aqui analisadas mostraram padrões diversos quanto aos postos de alto escalão.

Este estudo inova ao analisar o padrão de setores dentro dos órgãos ministeriais, além de propor uma análise mais aprofundada. Por meio de pesquisa documental e das bases citadas, foram analisados os perfis, as trajetórias e as vinculações dos/as ocupantes do maior posto em cada secretaria entre 2011 e $2018^{8}$. O recorte temporal abrange, portanto, três mandatos presidenciais: Rousseff I, Rousseff II e Temer. Os fatores considerados na análise dos perfis e das trajetórias correspondem à atuação partidária, ao vínculo associativo e ao nível de instrução, entre outros. Assim, identificou-se em que medida os padrões de nomeação observados se aproximam ou distanciam das previsões teóricas e das estatísticas gerais.

6 Abrangendo uma escala de 0 a 8, o índice é estimado segundo os seguintes critérios: ocupação de cargo eletivo, filiação a partido; ocupação de cargo em direção partidária; experiência profissional prévia; formação acadêmica em nível de pós-graduação e atuação como servidor público de carreira. Para os fins deste trabalho, considerei como experiência profissional a ocupação de cargos de gestão e a experiência no setor privado correlacionado, enquanto a direção partidária incluiu lideranças e vice-lideranças. Foram calculados os índices para cada um dos mandatos (Rousseff I, Rousseff II e Temer), assim como as médias de todo o recorte temporal para cada órgão.

7 A análise de secretarias dentro dos órgãos permite verificar as diferenças internas, visto que os ministérios não são atores monolíticos. As secretarias foram escolhidas devido ao caráter finalístico de suas atividades, à permanência na atual estrutura organizacional e à disponibilidade dos dados. As próximas fases da pesquisa estenderão a análise a todas as secretarias finalísticas.

8 Informações foram complementadas pelos dados disponíveis no Centro de Pesquisa e Documentação de História Contemporânea do Brasil (CPDOC) da Fundação Getúlio Vargas (FGV). 


\section{Nomeações a cargos públicos no Brasil (2011-2018)}

Um panorama geral dos quadros burocráticos

Existem duas formas de ingresso no serviço público brasileiro: concurso e indicação. Os cargos de livre provimento incluem aqueles de Direção $e$ Assessoramento (DAS) e as Funções Comissionadas do Poder Executivo (FCPE), as quais são destinadas exclusivamente a servidores/as de carreira. As pesquisas sobre "politização da burocracia" se concentram nos cargos DAS, uma vez que, para tais cargos, é possível nomear indivíduos sem vínculo efetivo com o serviço público. Entretanto, o percentual de filiados/as ocupando tais cargos é baixo e não chegou a $20 \%$ no período analisado.

Parte relevante dos cargos DAS é ocupada por servidores/as de carreira, cujo provimento primário ocorreu mediante concurso público. Além disso, nos últimos anos, notou-se um aumento progressivo na quantidade de cargos FCPE, ocupados exclusivamente por servidores/as de carreira, em consonância a uma diminuição na quantidade de cargos DAS. Em 2014, existiam 23.008 cargos DAS e apenas 1.923 cargos FCPE. Em 2018, tais números tornaram-se mais próximos: 11.566 cargos DAS e 11.606 cargos FCPE (dados do $\mathrm{PEP})^{9}$. O salto na relação entre cargos ocorreu entre 2016 e 2017 (cf. Figura 1) em decorrência do Decreto $n^{\circ} 8.785$ de 10 de junho de $2016^{10}$, e da Medida Provisória 731, que transformaram 10.462 cargos DAS em FCPE.

Figura 1 - Quantidade de cargos DAS e FCPE (2011-2018)

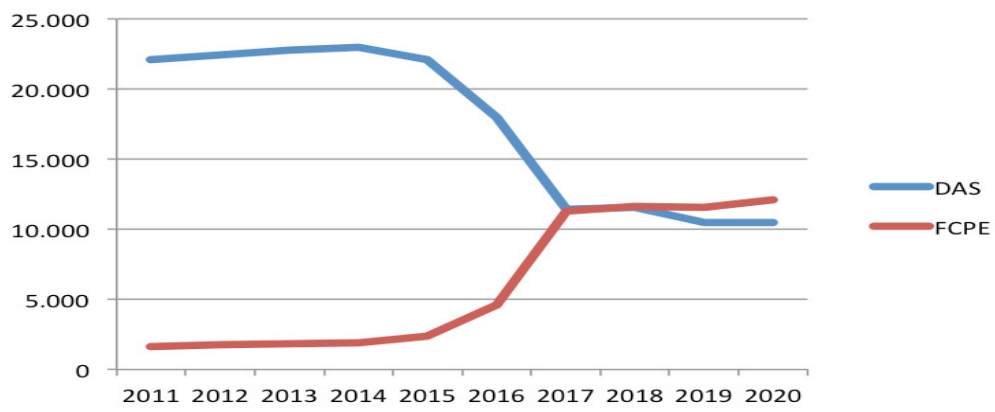

Fonte: Elaboração da autora, com base em dados do PEP.

9 Disponível em: https://dados.gov.br/aplicativo/painel-estatistico-pessoal-pep. Acesso em: out. 2020. Mês de referência: dezembro.

10 Revogado pelo Decreto n 9.725, de 12 de março de 2019 
Esse movimento converge com uma tendência geral nos últimos 10 anos em relação à ampliação do número de servidores de carreira em cargos de gestão (GUIMARÃES, PERLIN; MAIA, 2019). Durante o governo de Michel Temer, o Decreto no 9.021, de 2017, alterou o Decreto no 5.497, de 21 de julho de 2005, que estabelece limites para a discricionariedade das nomeações. Segundo as novas regras, $50 \%$ dos cargos DAS de 1 a 4 e $60 \%$ dos cargos DAS 5 e 6 deveriam ser destinados a servidores de carreiras estatais. De acordo com a literatura (GUIMARÃES; PERLIN; MAIA, 2019; LOPEZ; PRAÇA, 2018; LOPEZ; SILVA, 2019), isso limitaria a influência político-partidária. Entretanto, há duas ressalvas importantes a ser feitas. Primeiro, vale destacar que o aumento de cargos FCPE atingiu particularmente os níveis 1-4, de baixo e médio escalão, uma vez que a quantidade de cargos DAS 5 e 6 manteve-se relativamente estável (cf. Figura 2).

Figura 2 - Quantidade de cargos DAS, por nível

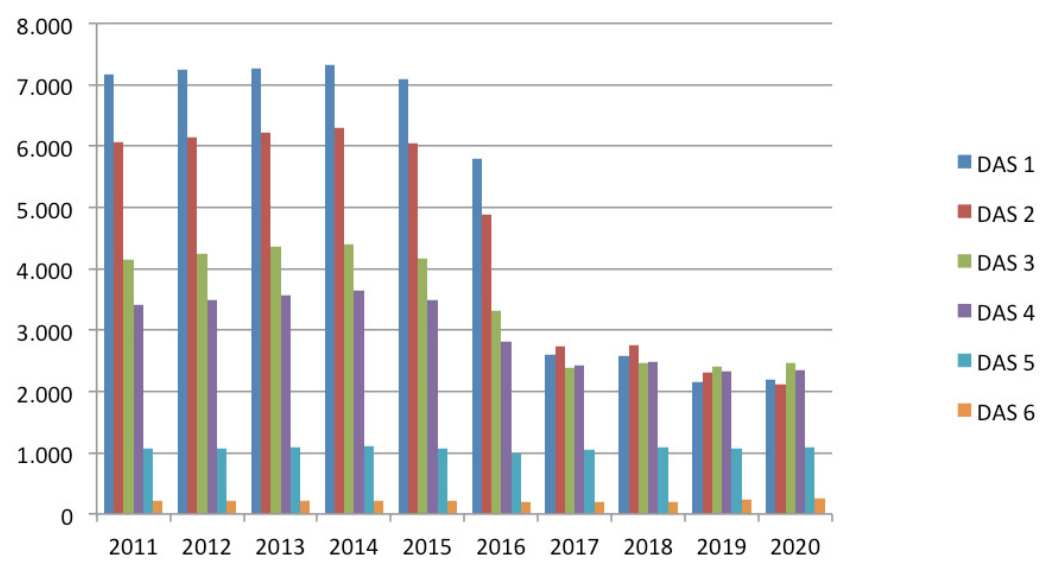

Fonte: Elaboração da autora, com base em dados do PEP.

Além disso, o número de servidores/as de carreira diminui progressivamente conforme aumenta o nível hierárquico assim como a quantidade de filiados/as aumenta, elemento já exposto pela literatura (LOPEZ; SILVA, 2019). Ainda assim, a quantidade de filiados/as é baixa considerando todo o universo do serviço público. Mesmo o percentual máximo de filiados/as ocupando postos 
DAS-6 não passou de 32\% no período"1 diminuindo para 25,7\% em 2018. Já o percentual de filiados/as ocupando DAS-5 é próximo à fração correspondente ao conjunto geral de DAS (entre 10 e $20 \%$ ).

Entre os/as ocupantes dos postos DAS 5 e 6 filiados/as a partidos, a presença da base aliada é maior. No entanto, o percentual representava uma fração pequena em comparação ao conjunto de cargos públicos mesmo antes dos normativos, enquanto a nomeação de funcionários/as de carreira pareceu ser a regra predominante. Nos cargos de nível 6, o percentual de funcionários/as de carreira oscilou entre 50\% e 60\% na última década, segundo os dados do Atlas. A fração de servidores/as efetivos é ainda maior nos cargos de menor nível hierárquico.

Ademais, é preciso observar, de forma mais detida, as competências relacionadas às nomeações em um recorte temporal estendido. Historicamente, os/as ministros/as de Estado desempenharam um papel importante no processo devido à delegação de competência, ainda que as nomeações sejam coordenadas por órgãos da Presidência. Durante o mandato de Temer, a Casa Civil continuou a ser responsável pelo provimento dos cargos DAS 5-6, além do/a Chefe de Assessoria Parlamentar e do/a titular de órgão jurídico da ProcuradoriaGeral Federal junto às autarquias e às fundações públicas federais. Os demais cargos ficaram a cargo dos/as ministros/as (Decreto $n^{\circ} 8.821$, de 26 de julho de 2016). Isso não exclui, porém, a possibilidade de uma subdelegação informal.

Nessa direção, a literatura brasileira prevê que a subdelegação é mais provável em algumas circunstâncias. Segundo Borges e Coêlho (2015), há maior chance de delegação quanto maior a distância ideológica entre o/a presidente e a coalizão. Por outro lado, entrevistas (LOPEZ; PRAÇA, 2015) mostraram que usualmente os/as subordinados/as dos/as ministros/as têm certa autonomia para escolher suas equipes. Assim, as regras formais não são os únicos fatores que afetam os padrões de escolhas e os perfis dos/as nomeados/as. Seria necessário observar a aplicação dessas regras em cada órgão para averiguar como os dirigentes implementam os dispositivos.

Isso levanta dúvidas quanto ao papel das nomeações no presidencialismo de coalizão. O argumento de que a nomeação a cargos é uma ferramenta do/a presidente para manter o apoio da coalizão parte da premissa de que os

11 O pico foi em $2015(31,2 \%)$. 
partidos e o presidente possuem certo controle sobre esse processo. Embora a Casa Civil tenha um papel importante no provimento de tais cargos, ministros/as e seus subordinados também são relevantes. Ao passo que o posto de ministro/a é um alvo mais evidente da cobiça partidária, é difícil assumir que os partidos possuem tal nível de controle e coesão em relação ao conjunto dos cargos DAS, principalmente os de níveis intermediário e inferior (DAS 1-4).

Nesse sentido, de acordo com Sorauf (1959), a utilidade do conceito de "patronagem" como recompensa ou incentivo é superestimada. O uso e a administração da patronagem, na prática, são difíceis, porque requerem certas habilidades que poucos políticos ou partidos possuem. Nessa perspectiva, redes informais - como laços de sangue ou de amizade - comprometeriam a disciplina política necessária à prática (SORAUF, 1959). Além disso, os estudos focam nos dilemas presidenciais ou parlamentares (GEDDES, 1994), mas os/as próprios/as funcionários/as também podem influenciar os processos de escolha de suas equipes.

A etapa qualitativa desta pesquisa analisou as trajetórias dos/as ocupantes dos cargos mais altos em três secretarias de três pastas ministeriais: "cultura", "ciência e tecnologia" e "agricultura"12. Nos órgãos analisados, outros vínculos políticos mostraram-se relevantes, mesmo para nomeados/as advindos/ as de carreiras públicas. Além disso, os casos específicos não apresentam tantas evidências que sustentem o argumento de que os cargos DAS nos ministérios são utilizados como "moeda de troca" entre presidente e partidos.

\section{Secretaria de Direitos Autorais e Propriedade Intelectual (Cultura)}

A estrutura que deu origem à SDAPI remete à Diretoria de Direitos Intelectuais (DDI). Em 2011, essa diretoria era chefiada por um servidor da carreira do ciclo de gestão, com trajetória acadêmica na área de antropologia. O cargo ocupado consistia em um DAS-5. O servidor havia trabalhado na área de direitos autorais quando a Diretoria era apenas uma CoordenaçãoGeral da Secretaria de Políticas Culturais. Após a chegada da ministra Ana de Hollanda, tal diretor foi substituído por uma advogada do setor privado. $\mathrm{Na}$ ocasião, a substituição causou forte repercussão, porque a advogada era próxima

12 Os cargos analisados referem-se a DAS-6. No entanto, na SDAPI (Cultura), a análise foi estendida para cargos DAS-5 em razão das modificações estruturais do setor (que foi uma Diretoria e um Departamento). Essas mudanças também fizeram com que a análise da SDAPI ocupasse maior espaço no texto. 
ao Escritório Central de Arrecadação e Distribuição (Ecad), ente privado que a gestão anterior visava regular ${ }^{13}$. Com a saída de Hollanda no ano seguinte, o mesmo diretor assumiria novamente o posto permanecendo até a destituição de Dilma Rousseff.

O resultado do retorno do antigo diretor foi a aprovação de normati$\operatorname{vos}^{14}$ que instituíam a fiscalização estatal do Ecad, conforme almejava a gestão prévia. Os ministros da Cultura no período foram Marta Suplicy e Juca Ferreira, cujas atuações estiveram vinculadas ao Partido dos Trabalhadores $(\mathrm{PT})^{\mathbf{1 5}}$, o partido da presidenta. Juca Ferreira deixou o posto em 2016, quando Michel Temer assumiu a Presidência da República. No mesmo ano, a diretoria foi transformada em Departamento no âmbito de uma reestruturação administrativa. Após polêmicas em torno da extinção do órgão, o Ministério da Cultura (MinC) foi recriado sob a direção do diplomata Marcelo Calero, na época filiado ao Partido do Movimento Democrático Brasileiro (PMDB), o partido do presidente.

A própria recriação do órgão denota a relação entre administração e processo político, tendo em vista que a decisão decorreu dos protestos realizados em todo o país contra a extinção do órgão. Na gestão de Calero, a DDI passou a integrar a Secretaria de Economia da Cultura (SEC), comandada por um advogado da área de propriedade intelectual. Em sua trajetória profissional, tal advogado configurara como representante do Sindicato Interestadual da Indústria Audiovisual (SICAV) e membro do conselho da Associação Brasileira de Propriedade Intelectual (ABPI). Na época, o novo diretor do DDI consistia em um advogado do setor privado.

A saída do diretor anterior do ministério acarretou novamente insatisfação de alguns stakeholders, notadamente parte da classe artística mobilizada mediante dois grupos: "Associação Procure Saber" e "Grupo de Ação Parlamentar". Ambos haviam sido atuantes no debate sobre direitos autorais, sobretudo em relação à reforma da gestão coletiva defendida pela gestão anterior e implementada após a saída de Hollanda (VALENTE, 2018).

Por outro lado, Calero abriu um processo seletivo para ampliar as nomeações de servidores/as da carreira do Ministério em cargos de comissão

13 Disponivel em: https://farofafa.cartacapital.com.br/2012/03/20/exclusivo-convite-do-senado-a-ana-de-hollandapode-virar-convocatoria/. Acesso em: 25 fev. 2021.

14 Lei 12.853 , de 2013, e os decretos e as instruções normativas que a regularam.

15 Marta Suplicy rompeu com o PT. 
("programa de valorização") ${ }^{16}$. Entretanto, tal processo não afetou a chefia do DDI, cuja indicação aparenta ter partido de membros da indústria tendo em vista a trajetória e a vinculação das pessoas que assumiram os cargos e a ausência de vínculo com o serviço público de ambos os nomeados. O secretário indicado por Calero foi exonerado pouco após a saída do ministro, mas o diretor manteve-se em seu posto até 2018. Calero, por sua vez, foi substituído por Roberto Freire e posteriormente João Batista (interino), ambos filiados ao Partido Popular Socialista (PPS), que integrava a base de Michel Temer17.

O novo secretário que assumiu a SEC, em janeiro de 2017, ocupara anteriormente o posto de diretor da Câmara Brasileira do Livro (CBL), associação privada que representa o mercado editorial18. Por fim, em 2018, o DDI se transformou em SDAPI ${ }^{19}$, passando a ter dois departamentos que foram comandados por duas servidoras da carreira do ministério com prévia experiência em gestão. Uma delas era filiada ao Partido da República (PR), mas os dados não permitem analisar a importância do vínculo. O novo secretário (DAS-6), vinculado ao partido REDE, foi provavelmente uma indicação pessoal do novo ministro, Sérgio Sá Leitão, tendo em vista que ambos atuaram na Agência Nacional de Cinema (Ancine).

Comparando-se a trajetória dos ocupantes dos cargos de direção mais importantes do setor, nota-se a priori uma mudança de perfil. Observa-se que o cerne das trajetórias profissionais se deslocou do setor público para o mercado. Após o impeachment de Rousseff, os ocupantes seguintes do cargo foram indivíduos que possuíam algum vínculo direto com a indústria de conteúdo, a mais importante parte interessada nesse subsistema de políticas. Essa mudança de perfil refletiu-se nos posicionamentos públicos adotados pelo setor. $\mathrm{O}$ discurso institucional que antes focava no acesso às obras e nos direitos culturais passou a conferir maior ênfase nas relações econômicas.

Isso se reflete em diferentes fontes de evidências, como a estrutura organizacional do setor e as agendas das autoridades. A própria vinculação do Departamento à SEC ressalta a mudança na abordagem. Uma

16 Disponível em: http://cultura.gov.br/valorizacao-do-servidor-e-prioridade-para-marcelo-calero/. Acesso em: 20 out. 2020.

17 O PPS deixou a base após o agravamento da crise política. Mudou de nome ("Cidadania") em 2019.

18 Em 2018, a SEC passou a se chamar "Secretaria de Economia Criativa" (Decreto $n^{\circ} 9.411$, de 18 de junho de 2018).

19 Ibidem. A estrutura funcional foi mantida na Secretaria Especial da Cultura (SECULT), vinculada ao Ministério da Cidadania, conforme o Decreto $n^{\circ} 9.674$, de 02 de janeiro de 2019 , revogado pelo Decreto $n^{\circ} 10.357$, de 20 de maio de 2020, quando a SECULT passou para o Ministério do Turismo. 
evidência adicional foi o reforço no combate à pirataria. $\mathrm{O}$ diretor da gestão de Calero fora secretário-executivo e vice-presidente do Conselho Nacional de Combate à Pirataria (CNCP) do Ministério da Justiça ${ }^{20}$. O próprio ministro recebera, em agosto de 2016, membros do Fórum Nacional Contra a Pirataria e a Ilegalidade (FNCP) ${ }^{21}$. A partir de junho de 2018, a recém-construída SDAPI passou a contar com uma Coordenação-Geral inteira voltada especificamente ao tema, que não integrava explicitamente as competências originais do setor.

Na DDI/SDAPI, não predominaram as indicações partidárias, considerando que a maioria dos/as nomeados/as não era vinculada formalmente a partidos, nem possuía atuação política profissional. Embora não seja possível excluir totalmente a atuação partidária, a trajetória e os vínculos dos/as nomeados/as indicam maior envolvimento de grupos ou entidades representativas do mercado. A CBL e a ABPI, por exemplo, caracterizam-se como organizações de defesa de interesses. De forma semelhante, o diretor que assumiu após a saída de Rousseff participara do CNCP, composto por empresas e entidades de classe interessadas no combate à pirataria, histórica demanda do mercado. Ao passo que o ministério foi comandado pelo PT, PMDB e PPS durante o período, isso não se refletiu nos cargos da SDAPI. O setor também apresentou alta taxa de rotatividade.

\section{Secretaria de Desenvolvimento e Inovação (Ciência e Tecnologia)}

A Secretaria de Desenvolvimento Tecnológico e Inovação (SETEC) integrou a estrutura regimental do Ministério de Ciência, Tecnologia, Inovação e Comunicações (MCTIC) até a reforma administrativa de 2019, quando foi substituída pela Secretaria de Empreendedorismo e Inovação. Assim como o MinC, a pasta também sofreu modificações relevantes durante os últimos anos - passando a incorporar o Ministério das Comunicações na gestão de Temer22. A rotatividade no posto mais alto do setor foi igualmente alta, semelhante ao padrão observado na DDI/SDAPI.

20 Portaria $n^{0}$ 1.563, de 19 de outubro de 2012. Disponível em: https://www.in.gov.br/. Acesso em: 26 out. 2020.

21 Disponivel em: http://www.fncp.org.br/forum/release/266 e http://cultura.gov.br/calero-defende-agendaconjunta-com-entidades-de-combate-a-pirataria/. Acesso em: 2 nov. 2020.

22 A fusão foi formalizada na Medida Provisória no 726, de 12 de maio de 2016. Disponível em: https://pesquisa. in.gov.br/imprensa/jsp/visualiza/index.jsp?data=12/05/2016\&jornal=1000\&pagina=3\&totalArquivos=10. Acesso em: 29 out. 2020. Vale ainda ressaltar que o Ministério das Comunicações foi recriado em 2020, mediante a Medida Provisória $n^{\circ}$ 980, de 2020. Disponível em: https://www.congressonacional.leg.br/materias/medidasprovisorias/-/mpv/142490. Acesso em: 29 out. 2020. 
De 2011 a 2018, o ministério teve cinco pessoas diferentes ocupando o cargo de Secretário na SETEC. Uma delas, porém, ocupou o mesmo posto em dois períodos distintos: de 2012 a 2014 e de 2016 a 2018. Da análise de suas trajetórias profissionais, verifica-se que quatro dos secretários nomeados eram professores de magistério superior. A análise das nomeações confirma, a priori, o que a literatura prevê sobre o "caráter técnico" do ministério: os ocupantes dos cargos possuíam nível alto de instrução e pertenciam ao mesmo domínio de atuação. Além disso, destaca-se que o padrão das nomeações possui uma tendência mais endógena em relação à pasta cultural, uma vez que grande parte dos secretários ocupara anteriormente outros cargos dentro do próprio Ministério. Apenas um dos secretários era filiado a partido (PT), mas a filiação ocorreu apenas em 2020, posteriormente ao exercício do cargo.

Os ocupantes destacam-se por obter um maior nível de instrução formal, além da experiência profissional dentro do órgão. A partir de 2018, houve uma pequena mudança no perfil: ainda que o secretário (que assumiu em março) tivesse formação em engenharia, ele não era professor de magistério superior como seus antecessores. Ademais, durante o mandato de Temer, o perfil dos ministros manteve maior índice de partidarização em comparação aos períodos anteriores analisados por Borges \& Coêlho (2015). Entre 2011 e 2018, o ministério foi comandado por partidos diversos: PT, PCdoB, PMDB e PSD. As atuações partidárias dos ministros não se refletiram, porém, na composição dos cargos mais altos na SETEC, na qual a filiação partidária não teve impacto relevante. Isso reforça as diferenças entre as dinâmicas que permeiam a escolha de ministros/as e as nomeações a cargos comissionados, por vezes obscurecidas na literatura especializada.

\section{Secretaria de Defesa Agropecuária (Agricultura)}

Das três secretarias analisadas, a SDA foi a que sofreu menores mudanças institucionais, tanto em termos de estrutura quanto em relação às nomeações. Quanto ao cargo de Ministro, houve menos diversidade partidária em comparação às pastas da cultura e da ciência e tecnologia, visto que a pasta foi comandada majoritariamente pelo PMDB durante o período. Vale ainda ressaltar que grande parte dos/as ministros/as guardava relação com a Frente Parlamentar da Agropecuária (FPA), um bloco suprapartidário. 
A chamada bancada ruralista geralmente se posiciona em relação às indicações para o cargo mais alto do Ministério. Sobre esse aspecto, é importante considerar que a bancada representa diversas associações do setor agropecuário. O nome de Blairo Maggi, por exemplo, foi explicitamente apoiado pelo setor ${ }^{23}$. Dos registros disponíveis na página da imprensa nacional, verifica-se que quatro pessoas ocuparam o posto mais alto cargo da SDA no período analisado. A maioria pertencia aos quadros da carreira do ministério. Esse padrão condiz com os dados gerais que mostram a concentração das nomeações de cargos comissionados em servidores/as de carreira, ainda que a fração diminua conforme o nível hierárquico. Ainda assim, vale destacar que, no caso da secretaria, grande parte dos/as servidores/as pertencia especificamente à carreira do ministério ${ }^{24}$. Por outro lado, a maioria era também filiada a partidos ou exerceu atividade política profissional.

Um dos secretários, funcionário cedido do Banco do Brasil, era filiado ao Partido Progressista (PP) desde 2009, mas o vínculo foi cancelado em 2013 a pedido do eleitor ${ }^{25}$ antes que ele assumisse o posto (em 2014). Durante o período de exercício do cargo, ele não esteve filiado formalmente a partido. Esse mesmo secretário chegou a ser preso pela Polícia Federal, em decorrência de supostos acordos ilegais com a JBS ${ }^{26}$. Anos antes da prisão, o jornal Valor Econômico havia divulgado que o deputado Eduardo Cunha - também envolvido no processo - havia indicado pessoalmente o nomeado para o cargo mediante ofício enviado ao ministro da Agricultura ${ }^{27}$. Cunha era então líder do PMDB, mesmo partido ao qual pertencia o ministro Andrade, antecessor de Neri Geller.

Foi divulgado na mídia que as nomeações desagradaram entidades do setor, tais como a Confederação da Agricultura e Pecuária da Brasil (CNA), presidida pela então senadora Kátia Abreu (na época do PSD-TO), que viria a se tornar ministra da Agricultura e passaria a integrar o PMDB. Assim, as evidências apontam um embate entre parlamentares envolvendo ainda entidades

23 Disponível em: https://www.canalrural.com.br/noticias/bancada-ruralista-apoia-blairo-maggi-para-ministerioagricultura-62001/. Acesso em: 3 nov. 2020.

24 Vale destacar que o serviço público compreende diferentes carreiras. Estima-se que a proporção de servidores/as dos próprios órgãos ocupando cargos comissionados seja ainda menor considerando o papel de funcionários/as como os/as especialistas em gestão.

25 As bases de dados relativas às filiações partidárias estão disponíveis na página do Tribunal Superior Eleitoral (TSE): https://www.tse.jus.br/. A "Base dos Dados Mais" permite consulta mais simples mediante o nome dos/as filiados/as: https://basedosdados.github.io/mais/ Acesso em: 28 jun. 2021.

26 Disponível em: https://www.conjur.com.br/dl/restricao-foro-especial-permitiu-vice.pdf. Acesso em: 4 nov. 2020.

27 Disponível em: https://www.avisite.com.br/clipping/imprimir.php?codclipping=21835. Acesso em: 4 nov. 2020. 
representativas de classe. O secretário nomeado em dezembro de 2015 por Kátia Abreu permaneceu no cargo até janeiro de 2019, o que ressalta a resiliência da posição face às transformações no governo.

O tempo de permanência de cada ocupante demonstrou ser maior em comparação às outras duas secretarias analisadas, assim como o nível de rotatividade foi menor no período indicado. Diferentemente das outras secretarias, a filiação partidária teve mais presença no conjunto dos nomeados. $\mathrm{O}$ caso da SDA atenta também para a fluidez das relações entre grupos, burocratas, partidos e instituições políticas devido à pluralidade das posições dos agentes. Kátia Abreu, por exemplo, foi senadora pelo PSD, passou a integrar o $\mathrm{PMDB}$, partido que havia confrontado em relação à nomeação de um dos secretários, foi presidente da CNA (entidade de classe), membro da FPA e enfim ministra da Agricultura.

\section{Análise comparativa}

De forma geral, a filiação partidária dos ocupantes dos cargos mais altos não pareceu ter tanta relevância em comparação a outros atributos, tais como vínculos com o setor privado, redes pessoais (com os/as ministros/as), trajetória acadêmica ou ainda relação com blocos parlamentares. Dos cargos analisados, poucos/as ocupantes foram filiados a partidos durante o período de exercício e menor quantidade pertencia à base aliada. Além disso, não eram filiados/as aos partidos dos/as ministros/as. Isso confirma os achados da literatura mais recente sobre a importância de outros vínculos, inclusive com os próprios partidos políticos (LOPEZ; PRAÇA, 2018; LOPEZ; SILVA, 2019) ${ }^{\mathbf{2 8}}$. Em acréscimo, os casos mostram os potenciais impactos das nomeações nas políticas setoriais. O Quadro 1 resume a análise das três secretarias.

28 A realidade é distinta para o contexto municipal, no qual provavelmente a patronagem possui impacto maior (LOPEZ; SILVA, 2019). 
Quadro 1 - Análise das três secretarias

\begin{tabular}{|c|c|c|c|c|c|c|}
\hline Setor & $\begin{array}{c}\text { Domínio } \\
\text { de } \\
\text { políticas }\end{array}$ & Tipo & $\begin{array}{c}\text { IPM }^{\star} \\
\text { Por } \\
\text { mandato }\end{array}$ & Padrão geral & $\begin{array}{c}\text { Atores } \\
\text { principais }\end{array}$ & Resultados \\
\hline SDAPI & Cultura & Regulatória & $\begin{array}{c}\text { Rousseff I: } 4 \\
\text { Rousseff II: } 6 \\
\text { Temer: } 4\end{array}$ & $\begin{array}{l}\text { Relações } \\
\text { fortes com o } \\
\text { setor privado / } \\
\text { relações com } \\
\text { o mercado }\end{array}$ & $\begin{array}{c}\text { Grupos de } \\
\text { interesse }\end{array}$ & $\begin{array}{l}\text { Indicação mista } \\
\text { de membros do } \\
\text { setor privado e do } \\
\text { setor público } \\
\text { Alta rotatividade } \\
\text { Estabilidade } \\
\text { institucional baixa }\end{array}$ \\
\hline SETEC & $\begin{array}{l}\text { Ciência e } \\
\text { Tecnologia }\end{array}$ & Regulatória & $\begin{array}{c}\text { Rousseff I: } 3 \\
\text { Rousseff II: 4,6 } \\
\text { Temer: } 7\end{array}$ & $\begin{array}{c}\text { Relações } \\
\text { fortes com o } \\
\text { setor público } \\
\text { (universidades) }\end{array}$ & Desconhecido & $\begin{array}{l}\text { Indicação de servidores } \\
\text { de carreira com } \\
\text { vínculos formais com } \\
\text { o serviço público } \\
\text { Alta rotatividade } \\
\text { Estabilidade } \\
\text { institucional média }\end{array}$ \\
\hline SDA & Agricultura & Regulatória & $\begin{array}{c}\text { Rousseff I: } 7 \\
\text { Rousseff II: } 7 \\
\text { Temer: } 7\end{array}$ & $\begin{array}{c}\text { Relações } \\
\text { fortes com } \\
\text { associações } \\
\text { profissionais, } \\
\text { políticos e o } \\
\text { setor público }\end{array}$ & $\begin{array}{c}\text { Grupos de } \\
\text { interesse } \\
\text { Políticos } \\
\text { Frentes }\end{array}$ & $\begin{array}{c}\text { Indicação de servidores } \\
\text { de carreira do } \\
\text { próprio Ministério } \\
\text { Baixa rotatividade } \\
\text { Estabilidade } \\
\text { institucional alta }\end{array}$ \\
\hline
\end{tabular}

Legenda: * IPM (BORGES; COÊLHO, 2015), médias estimadas por mandato. Para o cálculo do IPM, não foram considerados os interinos. O mandato de Temer foi considerado a partir do afastamento de Rousseff em maio de 2016. Fonte: Elaboração da autora, com base em índice desenvolvido por Borges e Coêlho (2015).

Nos casos estudados, as evidências mostram proximidade com ministros/as e a atuação de segmentos sociais mobilizados, além da intervenção de parlamentares específicos. Por outro lado, a literatura especializada está centralizada na escolha dos presidentes, com uma clara influência dos estudos presidenciais estadunidenses, ao passo que seria necessário aprofundar os diferentes fatores que incidem sobre as escolhas dos/as ministros/as e outros potenciais subordinados para quem o poder de nomear pode ser delegado formal ou informalmente. O MCTI, considerado geralmente como pasta menos politizada, apresentou um índice médio de partidarização no período, mas isso não se refletiu no cargo mais alto da SETEC.

Em contraste, o MinC é considerado mais político em razão do componente partidário na trajetória dos ministros em comparação a outras pastas cujo papel da qualificação técnica é mais evidente. Entretanto, a vinculação partidária e a experiência na Administração Pública (indicadores respectivamente 
dos níveis de partidarização e de profissionalização) não são excludentes. $\mathrm{O}$ ministro Calero, por exemplo, era servidor de carreira (diplomata) filiado ao PMDB e hoje é deputado federal pelo partido Cidadania, o que reforça a fluidez das relações partidárias no Brasil.

É importante, portanto, considerar a natureza multidimensional do fenômeno e a inseparabilidade entre as variáveis explicativas. Em linhas gerais, ao tratar dos dilemas políticos, os estudos destacam reiteradamente duas lógicas decisórias que permeiam as práticas em relação às nomeações: $(i)$ a necessidade de garantir apoio; e (ii) a necessidade de garantir a implementação das políticas (GEDDES, 1994; LOUREIRO; OLIVIERI; MARTES, 2010)29. Entretanto, a busca por apoio e a implementação de políticas não são excludentes, visto que o apoio é necessário à implementação e a implementação está relacionada às chances de sobrevivência política (GEDDES, 1994; DOWNS, 1999).

Ademais, os casos reforçam as falhas da divisão entre "política" e "técnica” centrada na dicotomia entre vinculação partidária e qualificações técnicas. Mesmo nas áreas consideradas "técnicas", pode-se recorrer a grupos de interesse para escolher os ocupantes dos cargos. As qualificações não eliminam a natureza política da indicação, tendo em vista a presença constante de conflitos ideológicos nos campos. A área de direito autoral, por exemplo, é uma matéria de grande complexidade técnica, mas que não está imune aos conflitos políticos entre as coalizões que fazem parte do meio.

Os detentores do "conhecimento técnico" também apresentam divergências de interesses e de visões de mundo, o que caracteriza a política. Esses valores afetam o posicionamento e os resultados em termos de políticas públicas. Na SDAPI, o cargo foi ocupado por pessoas com experiência em propriedade intelectual, mas com perspectivas e trajetórias diferentes, o que se refletiu, de certa forma, nos posicionamentos adotados pelo setor ${ }^{30}$. As vinculações expressas dos ocupantes com entidades de defesa de interesses - ABPI, CBL, entre outras - podem trazer luz ao papel político adjacente aos cargos considerados "técnicos" e aos impactos nas políticas.

29 Bárbara Geddes (1994) destaca que o presidente necessita de ambas as lógicas (apoio e competência), tendo em vista seus três objetivos (sobrevivência política, eficiência e lealdade). A autora também menciona a necessidade de apoio para a implementação das políticas. Diferentemente de Geddes (1994), porém, não considero a "lealdade" um objetivo em si mesmo, mas um meio para alcançar os outros dois objetivos.

30 O posicionamento acerca de alguns temas relacionados a direitos autorais, sobretudo combate à pirataria, mudou com a troca da gestão. Ainda assim, a institucionalização de alguns tópicos por lei, tais como a fiscalização da gestão coletiva prevista, confere certo nível de continuidade às políticas. Destarte, os impactos das nomeações nos resultados das políticas consistem em um tema que merece maior estudo. 
O vínculo formal com o serviço público tampouco elimina a probabilidade de a indicação ser política. O ingresso no serviço por meio de concurso público não exclui a pré-existência de outras relações políticas, inclusive partidárias. Alguns/mas servidores/as de carreira eram filiados/as a partidos, ainda que isso talvez não tenha apresentado impactos relevantes nas nomeações. No período analisado, o Ministério da Agricultura, Pecuária e Abastecimento (MAPA) demonstrou ser claramente o mais partidarizado devido à predominância de ministros/as e secretários/as com vínculo partidário ou atuação política profissional. Por outro lado, a maioria dos/as nomeados/as pertencia à carreira do Ministério ou de outros órgãos públicos. Isso não excluiu a atuação de entidades representativas, tais como a CNA, que se manifestou publicamente contra a indicação de um dos nomeados, vinculado ao Banco do Brasil e que aparentemente fora indicado por um deputado.

Assim, cabe questionar os motivos por trás das nomeações de servidores provenientes das carreiras estatais para cargos de alta gestão, assunto pouco explorado pela literatura. Pode ser que a nomeação de servidores/as seja uma forma de cooptação ou de controle da burocracia estatal, tendo em vista que se trata de um sistema de incentivos mediante compensação salarial (PACHECO, 2002, 2008). Não por acaso, o ministro Calero instituiu um "programa de valorização" do contingente do órgão logo após as polêmicas e as manifestações de servidores/as contra a administração de Temer. Reforça-se, assim, a necessidade de ampliar os estudos para os cargos de tipo FCPE, tendo em vista o aumento progressivo da quantidade nos últimos anos e a existência dessas funções em postos de médio escalão nas estruturas das secretarias.

É necessário ainda aperfeiçoar a mensuração e a escolha de proxies na investigação dos mecanismos causais das nomeações. Os casos e as estatísticas mostram que a lógica dos dilemas presidenciais na nomeação de ministros/as pode não se reproduzir nas escolhas para outros cargos públicos. Ainda que os/ as ministros/as das três pastas, entre 2011 e 2018, pertencessem, em grande parte, aos partidos do/a presidente/a ou da coalizão, a partidarização não se refletiu nos órgãos de assistência. De forma geral, houve baixa presença dos partidos dos/ as ministros/as ou da base nos cargos comissionados das secretarias analisadas.

Os estudos assumem, como pressuposto, que o presidencialismo de coalizão resulta na necessidade de buscar ou manter apoio de diferentes 
partidos, o que, por sua vez, transformaria a alocação de cargos públicos em "moeda de troca". Entretanto, a baixa quantidade de filiados/as ocupando cargos DAS traz questionamentos a essas assertivas, ainda que o percentual seja maior para os cargos de maior nível hierárquico. Assim, é preciso analisar se as nomeações são representativas da correlação de forças do Congresso (GUIMARÃES; PERLIN; MAIA, 2019) para verificar a utilidade da alocação de cargos como estratégia. Nos casos analisados, os perfis dos/as burocratas indicaram a presença de grupos de interesse e organizações suprapartidárias. Face à falta de conhecimento dos dirigentes sobre os temas, é provável que eles recorram a grupos e segmentos politicamente atuantes no setor.

Assim, a divisão entre técnica e política conforme expressa nessa literatura restringe o significado de "política" à atuação institucional formal, sobretudo mediante a atividade partidária. Mas movimentos sociais e grupos de interesse também "fazem política". Proponho, portanto, uma ressignificação na classificação das nomeações: em vez de dividi-las com base nos termos amplos "técnica" e "política", sugiro identificar as possíveis fontes específicas da indicação conforme atividades e origens dos/as nomeados/as: pública-interna (quando se trata de servidor/a do próprio órgão), pública-externa (quando o servidor/a é proveniente de outro órgão ou de outras carreiras públicas), política-parlamentar (quando advinda de um partido ou de um político profissional), e civil (quando de origem na sociedade civil, subdividida de acordo com o tipo de organização: grupos de interesse, ONGs, entre outros).

Nesse sentido, índices visando mensurar o nível de politização devem considerar outros fatores além das filiações partidárias e da carreira política, como o envolvimento com organizações civis. Em 2008, Regina Pacheco já havia mencionado a necessidade de se considerar os diferentes tipos de competências necessárias ao exercício das atividades dos dirigentes públicos (não apenas o conhecimento técnico, mas também as habilidades gerais). Sugiro fazer o mesmo em relação à expertise política.

Como todas as nomeações possuem uma natureza política, é empiricamente mais útil analisar os componentes em seus conjuntos: competências gerenciais (de gestão e administração), competências técnicas (relacionadas à expertise sobre o objeto das políticas) e atuação política, a qual por sua vez pode ser partidária ou não. Esses componentes, que não são excludentes, 
podem ser utilizados para estimar os perfis dos/as burocratas de forma mais completa (como em KRAUSE; O'CONNELL, 2015). Nesse sentido, Lameirão e D’Araújo (2011) promovem um esforço maior em fornecer um perfil mais completo dos dirigentes públicos no que tange ao mandato Lula. A continuidade da agenda de pesquisa requer a extensão da análise a outros mandatos.

O envolvimento de outros atores no processo reforça a importância das instituições informais, ignoradas por essa literatura. Centrados em abordagens influenciadas pela escolha racional e pelo "novo institucionalismo", os estudos anteriores concentram-se na análise das instituições formais (BATISTA, 2016). As pesquisas mencionam, por exemplo, as regras quanto ao percentual de funções destinado a servidores efetivos (PRAÇA; FREITAS; HOEPERS, 2011; LOPEZ; BUGARIN; BUGARIN, 2013), mas não versam sobre a aplicação de tais regras nos respectivos órgãos.

Nos últimos anos, intensificou-se formalmente um movimento de diminuição de discricionariedade na escolha de cargos de livre provimento. Foram aprovados sucessivos decretos que aumentavam o percentual destinado a servidores de carreira, assim como reduziram a quantidade total de cargos DAS e, mais recentemente, determinaram certas regras para as nomeações. Entretanto, a redução atingiu particularmente os cargos DAS 1-4, pois a quantidade de cargos DAS níveis 5-6 manteve-se estável, com um pequeno aumento nos últimos dois anos. Além disso, é preciso analisar em que medida tais regras são cumpridas nos órgãos e como são interpretadas pelos agentes que as aplicam ${ }^{31}$.

É evidente que a análise das instituições informais enfrenta uma série de desafios metodológicos. Reforça-se, portanto, a importância de técnicas de coleta como surveys e entrevistas para levantar informações mais específicas sobre as motivações dos agentes. Ademais, o papel das redes interpessoais salienta a utilidade de métodos como a análise de redes sociais (LOPEZ; PRAÇA, 2018). Estudos comparativos mais aprofundados sobre trajetórias e vínculos podem igualmente fornecer mais informações sobre os padrões das nomeações. A triangulação de fontes e de técnicas qualitativas e quantitativas se mostra como a principal alternativa para lidar com os desafios metodológicos do campo.

31 Esses esforços podem sofrer mudanças com a aprovação da Medida Provisória n 1.042, de 14 de abril de 2021, que muda significantemente o sistema de cargos no Brasil. Como alguns de seus dispositivos produzem efeito apenas a partir de março de 2023, seus impactos restam desconhecidos. Disponível em: http://www.planalto.gov. br/ccivil_03/_Ato2019-2022/2021/Mpv/mpv1042.htm Acesso em: 28 jun. 2021. 
Outro elemento que poderia ser aprofundado é a existência de "territórios de domínio político", ou seja, o domínio de certas pastas por partidos específicos, verificado conforme recorrência das nomeações partidárias (MENEGUELLO, 1998). No período estudado, a cultura foi uma pasta ocupada majoritariamente pelo PT enquanto a pasta da agricultura foi dominada pelo PMDB. Entretanto, isso não se traduz necessariamente na ocupação dos demais cargos, uma vez que os/as dirigentes mais altos das secretarias analisadas não eram filiados a tais partidos. Seria ainda necessário analisar um período temporal mais largo e um número maior de secretarias para investigar os territórios de domínio político e como eles afetam as nomeações.

\section{Considerações finais}

Os casos aqui analisados divergem parcialmente em relação à literatura e aos dados gerais nos seguintes aspectos: o MCTI apresentou um nível maior de partidarização que o esperado no governo de Temer, os/as nomeados/as apresentaram um nível de instrução superior à média e funcionários/ as de carreira apresentaram vínculos políticos diferentes das filiações partidárias. Os dados gerais e os casos sugerem que a filiação não é o critério mais relevante nas nomeações, embora cresça a quantidade de filiados/as conforme o nível hierárquico.

Uma das principais lições do estudo consiste na observação de que as dinâmicas relativas à escolha dos/as ministros/as não se refletem necessariamente nos cargos subordinados. Pacheco (2002) já destacara a diferença de ethos entre ministros/as e presidentes. Segundo a autora, raramente os/as presidentes se encarregariam pessoalmente das nomeações, atribuídas geralmente aos/às ministros/as. A delegação ocorre a nível formal, segundo os decretos aprovados nos últimos anos, mas também pode acontecer informalmente. Considerando-se a desigualdade dentro do serviço público, as motivações podem variar também conforme o cargo ou função (DAS, FCPE, Natureza Especial, entre outros) e as carreiras (ciclo de gestão, "carreirão", entre outras), como aventa a autora.

Ainda que a literatura evoque frequentemente a alocação de cargos como ferramenta do/a presidente face ao contexto institucional brasileiro, a relação entre cargos e presidencialismo de coalizão não é uma verdade incontestável. 
Tendo em vista as recorrentes mudanças nas regras relativas às nomeações e nos papeis dos órgãos de coordenação da Presidência, estima-se que o estilo pessoal de governar do/a presidente também afeta a distribuição e os custos da patronagem.

Ante o exposto, sugere-se explorar os seguintes temas na continuidade da agenda de pesquisa:

I. As estratégias e lógicas que norteiam a alocação de cargos para servidores/as das carreiras efetivas;

II. O papel de grupos de interesse e dos estilos pessoais dos/as presidentes nas nomeações;

III. Os perfis dos/as dirigentes considerando as diferentes carreiras que integram o serviço público e os diversos tipos de competências relacionados às atividades;

IV. Os impactos das nomeações nas políticas (convergência entre agendas e resultados).

A análise dos elementos acima certamente contribuirá para aprofundar o conhecimento sobre a burocracia, agenda cara ao aperfeiçoamento do serviço público brasileiro.

\section{Referências}

ABERS, Rebecca; OLIVEIRA, Marília Silva de. Nomeações políticas no Ministério do Meio Ambiente (2003-2013): interconexões entre ONGs, partidos e governos. Opinião Pública, Campinas, v. 2, n. 2, p. 336-364, 2015. ABRUCIO, Fernando Luiz; LOUREIRO, Maria Rita. Burocracia e ordem democrática: desafios contemporâneos e experiência brasileira. In: PIRES, Roberto; LOTTA, Gabriela; OLIVEIRA, Vanessa Elias de (org.). Burocracia e políticas públicas no Brasil: intersecções analíticas. Brasília: IPEA, 2018. p. 23-57.

BARBERIA, Lorena; PRAÇA, Sérgio. Who gets political appointments? Party loyalty and bureaucratic expertise in Brazil. In: ENCONTRO DA ASSOCIAÇÃO BRASILEIRA DE CIÊNCIA POLÍTICA, 9., 2014, Brasília. Apresentações [...]. Brasília: ABCP, 2014. p. 1-14. Disponível em: https:// 
cienciapolitica.org.br/web/system/files/documentos/eventos/2017/03/who-gets-political-appointments-party-loyalty-and.pdf. Acesso em: 25 jun. 2021. BATISTA, Mariana. O poder no Executivo: explicações no presidencialismo, parlamentarismo e presidencialismo de coalizão. Revista de Sociologia e Política, Curitiba, v. 24, n. 57, p. 127-155, 2016.

BATISTA, Mariana; LOPEZ, Felix. Ministerial typology and political appointments: where and how do presidents politicize the bureaucracy. Brazilian Political Science Review, São Paulo, v. 15, n. 1, e-0004, p. 1-34, 2021. BEARFIELD, Domonic A. What is patronage? A critical reexamination. Public Administration Review, Washington, D.C., v. 69, n. 1, p. 64-76, 2009. BERSCH, Katherine; PRAÇA, Sérgio; TAYLOR, Matthew M. State capacity, bureaucratic politicization, and corruption in the Brazilian State. Governance - An International Journal of Policy, Administration, and Institutions, Oxford, v. 30, n. 1, p. 105-124, 2017.

BORGES, André; COÊLHO, Denilson Bandeira. O preenchimento de cargos da burocracia pública federal no presidencialismo de coalizão brasileiro: análise comparada de dois ministérios - Ciência e Tecnologia e Integração Nacional. In: LOPEZ, Felix Garcia (org). Cargos de confiança no presidencialismo de coalizão brasileiro. Brasília: IPEA, 2015. p. 71-105.

BRASIL. Presidência da República. Decreto no 8.785, de junho de 2016.

Dispõe sobre o remanejamento de cargos em comissão do Grupo-Direção e Assessoramento Superiores, de Funções Gratificadas e de Gratificações Temporárias de Atividade em Escola de Governo para a Secretaria de Gestão do Ministério do Planejamento, Desenvolvimento e Gestão. Brasília: Presidência da República, 2018. Disponível em: http://www.planalto.gov.br/ ccivil_03/_ato2015-2018/2016/decreto/D8785.htm. Acesso em: 26 nov. 2010.

BRASIL. Presidência da República. Decreto no 9.725, de 12 de março de 2019. Extingue cargos em comissão e funções de confiança e limita a ocupação, a concessão ou a utilização de gratificações. Brasília: Presidência da República, 2019. Disponível em: http://www.planalto.gov.br/ccivil_03/_ ato2019-2022/2019/decreto/D9725.htm. Acesso em: 26 nov. 2010.

BRASIL. Presidência da República. Medida Provisória no 731, de 10 de junho de 2016. Dispõe sobre a extinção de cargos em comissão do Grupo-Direção e Assessoramento Superiores e a criação de funções de confiança denominadas 
Funções Comissionadas do Poder Executivo. Brasília: Presidência da República, 2016. Disponível em: http://www.planalto.gov.br/ccivil_03/_ Ato2015-2018/2016/Mpv/mpv731.htm. Acesso em: 26 nov. 2010.

CAVALCANTE, Pedro; LOTTA, Gabriela; OLIVEIRA, Vanessa Elias de. Do insulamento burocrático à governança democrática: transformações institucionais e a burocracia no Brasil. In: PIRES, Roberto; LOTTA, Gabriela; OLIVEIRA, Vanessa Elias de (org.). Burocracia e políticas públicas no Brasil: intersecções analíticas. Brasília: IPEA, 2018. p. 59-83.

DOWNS, Anthony. Uma teoria econômica da democracia. Tradução de Sandra Vasconcelos. São Paulo: Editora da Universidade de São Paulo, 1999. EVANS, Peter. Autonomia e parceria: Estados e transformação industrial. Rio de Janeiro: Editora UFRJ, 2004.

GEDDES, Bárbara. Politician's dilemma: building state capacity in Latin America. Berkeley; Los Angeles: California University Press, 1994.

GOZETTO, Andréa Cristina; MANCUSO, Wagner Pralon. Lobby e políticas públicas. Rio de Janeiro: FGV Editora, 2018.

GUIMARÃES, André Rehbein Sathler; PERLIN, Giovana dal Bianco; MAIA, Lincoln Macário. Do presidencialismo de coalizão ao parlamentarismo de ocasião: as relações executivo-legislativo no Governo Dilma Rousseff. In: PERLIN, Giovana; SANTOS, Manoel Leonardo (org.). Presidencialismo de coalizão em movimento. Brasília: Câmara dos Deputados, 2019. p. 25-59. KEMAHLIOĞLU, Özge. Jobs in politicians backyards: party leadership competition and patronage. Journal of Theoretical Politics, London, v. 23, n. 4, p. 480-509, 2011.

KOPECKÝ, Petr, MAIR, Peter. Party Patronage in Contemporary Europe: Principles and Practices. European University Institute Working Paper, RSCAS 2011/41, p. 1-18, 2011. Available at: https://cadmus.eui.eu/bitstream/handle/1814/18057/ RSCAS_2011_41.pdf?sequence=1\&isAllowed=y. Accessed on: 25 jun. 2021. KRAUSE, George A.; O'CONNELL, Anne J. Experiential learning and presidential management of the U.S. Federal bureaucracy: logic and evidence from agency leadership appointments. American Journal of Political Science, Madison, v. 60, n. 4, p. 914-921, 2015.

LAMEIRÃO, Camila. Os níveis de controle da presidência sobre a coordenação política governamental e a coalizão partidária (1995-2010). In: LOPEZ, Felix 
Garcia (org.). Cargos de confiança no presidencialismo de coalizão brasileiro. Brasília: IPEA, 2015. p. 165-205.

LAMEIRÃO, Camila; D’ARAÚJO, Maria Celina. Dirigentes públicos de alto escalão no Governo Lula. In: CARDOSO JR., José Celso (org.). Burocracia e ocupação no setor público. Rio de Janeiro, 2011. p. 91-131.

LOPES, André Vaz; VIEIRA, Diego Mota. Nomeações para cargos comissionados e grupos de interesse: uso, motivações e desafios retratados em pesquisas recentes. Revista Eletrônica de Administração - REAd, Porto Alegre, v. 26, n. 2, p. 439-462, 2020.

LOPEZ, Felix Garcia. Introdução. In: LOPEZ, Felix Garcia (org.). Cargos de confiança no presidencialismo de coalizão brasileiro. Brasília: IPEA, 2015. p. 11-31. LOPEZ, Felix; BUGARIN, Maurício; BUGARIN, Karina. Mudanças político-partidárias e rotatividade dos cargos de confiança. In: LOPEZ, Félix Garcia (org.). Cargos de confiança no presidencialismo de coalizão brasileiro. Brasília: IPEA, 2015. p. 33-70.

LOPEZ, Felix; BUGARIN, Maurício; BUGARIN, Karina. Partidos, facções e a ocupação dos cargos de confiança no executivo federal (1999-2011). In: ENCONTRO ANUAL DA ASSOCIAÇÃO NACIONAL DE PÓSGRADUAÇÃO E PESQUISA EM CIÊNCIAS SOCIAIS, 37., 23-27 set. 2013, Águas de Lindóia. Anais [...]. Águas de Lindóia: ANPOCS, 2013. Disponível em: https://www.anpocs.com/index.php/encontros/papers/ 37-encontro-anual-da-anpocs/st/st03. Acesso em: 25 jun. 2021.

LOPEZ, Felix; PRAÇA, Sérgio. Cargos de confiança e políticas públicas no Executivo federal. In: PIRES, Roberto; LOTTA, Gabriela; OLIVEIRA, Vanessa Elias de (org.). Burocracia e políticas públicas no Brasil: intersecções analíticas. Brasília: IPEA, 2018. p. 141-159.

LOPEZ, Felix; PRAÇA, Sérgio. Critérios e lógicas de nomeação para o alto escalão da burocracia federal brasileira. In: LOPEZ, Felix Garcia (org.). Cargos de confiança no presidencialismo de coalizão brasileiro. Brasília: IPEA, 2015. p. 107-138.

LOPEZ, Felix; SILVA, Thiago Moreira da. Filiações partidárias e nomeações para cargos da burocracia federal (1999-2018). Revista de Administração Pública, Rio de Janeiro, v. 53, n. 4, p. 711-731, 2019.

LOSEKANN, Cristiana. Participação da sociedade civil na política ambiental 
do Governo Lula. Ambiente \& Sociedade, São Paulo, v. 15, n. 1, p. 179200, 2012.

LOUREIRO, Maria Rita; OLIVIERI, Cecília; MARTES, Ana Cristina Braga. Burocratas, partidos e grupos de interesse: o debate sobre política e burocracia no Brasil. In: LOUREIRO, Maria Rita; ABRUCIO, Fernando Luiz; PACHECO, Regina Silvia. Burocracia e política no Brasil contemporâneo. Rio de Janeiro: Ed. FGV, 2010. p. 73-108.

MANCUSO, Wagner Pralon. O lobby da indústria no Congresso Nacional: empresariado e política no Brasil contemporâneo. DADOS - Revista de Ciências Sociais, Rio de Janeiro, v. 47, n. 3, p. 505-547, 2004.

MENEGUELLO, Rachel. Partidos e governos no Brasil contemporâneo (1985-1997). São Paulo: Paz e Terra, 1998.

NUNES, Edson. A gramática política do Brasil: clientelismo e insulamento burocrático. Rio de Janeiro: Zahar, 1997.

O'DWYER, Conor. Runaway State-building: patronage politics and democratic development. Baltimore: The Johns Hopkins University Press, 2006.

PACHECO, Regina Silvia. Brasil: o debate sobre dirigentes públicos. Atores, argumentos e ambigüidades. In: CONGRESO INTERNACIONAL DEL CLAD SOBRE LA REFORMA DEL ESTADO Y DE LA ADMINISTRACIÓN PÚBLICA, 13., nov. 2008, Buenos Aires. Anais [...]. Buenos Aires: CLAD, 2008. Disponível em: https://www.researchgate.net/profile/Regina-SilviaPacheco/publication/266911055_Brasil_o_debate_sobre_dirigentes_publicos_atores_argumentos_e_ambiguidades/links/543ebba40cf2e76f02242ff3/ Brasil-o-debate-sobre-dirigentes-publicos-atores-argumentos-e-ambiguidades. Acesso em: 25 jun. 2021.

PACHECO, Regina Silvia. Mudanças no perfil dos dirigentes públicos no Brasil e desenvolvimento de competência de direção. In: CONGRESO INTERNACIONAL DEL CLAD SOBRE LA REFORMA DEL ESTADO Y LA ADMINISTRACIÓN PÚBLICA, 7., 8-11 out. 2002, Lisboa. Anais [...]. Lisboa: CLAD, 2002. Disponível em: https://pesquisa-eaesp.fgv.br/sites/ gvpesquisa.fgv.br/files/arquivos/regina_monnteiro_-_cambio.pdf. Acesso em: 25 jun. 2021.

PRAÇA, Sérgio; FREITAS, Andrea; HOEPERS, Bruno. Political appointments and coalition management in Brazil, 2007-2010. Journal of Politics in Latin 
America, [Online], v. 3, n. 2, p. 141-172, 2011.

RECH, Carla. Entre os movimentos sociais e o Estado: uma análise do trânsito de indivíduos entre órgãos estatais e organizações de movimentos sociais no Brasil. 2020. Tese (Doutorado em Sociologia) - Programa de Pós-Graduação em Sociologia, Institut de Filosofia e Ciências Humanas, Universidade Federal do Rio Grande do Sul, Porto Alegre, 2020. Disponível em: https://lume.ufrgs.br/handle/10183/213052. Acesso em: 25 jun. 2021.

SANTOS, Luiz Alberto dos. Regulamentação das atividades de lobby e seu impacto sobre as relações entre políticos, burocratas e grupos de interesse no ciclo de políticas públicas - análise comparativa dos Estados Unidos e Brasil. 2007. Tese (Doutorado em Ciências Sociais) - Programa de Pós-Graduação em Estudos Comparados sobre as Américas, Instituto de Ciências Sociais, Universidade de Brasília, Brasília, 2007. Disponível em: https://repositorio.unb.br/handle/10482/1483. Acesso em: 25 jun. 2021.

SCHERLIS, Gerardo. The contours of party patronage in Argentina, Latin American Research Review, [Online], v. 48, n. 3, p. 63-84, 2013.

SORAUF, Frank J. Party and patronage. Midwest Journal of Political Science, [Online], v. III, n. 2, p. 115-126, 1959.

VALENTE, Mariana Giorgetti. Reconstrução do debate legislativo sobre direito autoral no Brasil: os anos 1989-1998. 2018.Tese (Doutorado em Direito) - Faculdade de Direito, Universidade de São Paulo, São Paulo, 2018. Disponível em: https://www.teses.usp.br/teses/disponiveis/2/2139/ tde-21082020-154540/pt-br.php. Acesso em: 25 jun. 2021.

ZUCCO JR., Cesar; BATISTA, Mariana; POWER, Timothy J. Measuring portfolio salience using the Bradley-Terry model: An illustration with data from Brazil. Research and Politics, [Online], p. 1-8, 2019. DOI: https:// doi.org/10.1177\%2F2053168019832089. Acesso em: 29 jun. 2021.

Reflexões sobre nomeações a cargos públicos no Brasil: a experiência de três secretarias entre 2011 e 2018

Resumo: O objetivo deste artigo é discutir os desafios e as potencialidades das pesquisas sobre politização da burocracia no Brasil. Para tanto, o artigo apresenta uma revisão integrativa da literatura, uma análise exploratória de dados e estudos aprofundados de três casos relativos à ocupação de cargos 
em órgãos ministeriais entre 2011 e 2018 . O artigo destaca as lacunas da literatura no que tange ao papel de grupos de interesse no processo de nomeação a postos de alto escalão. Como poucos estudos tratam do lobby nas decisões relativas às nomeações, recorre-se à literatura especializada sobre política de pressão. Ademais, a análise de três secretarias nacionais de diferentes domínios de políticas públicas oferece aportes teóricos à classificação e à mensuração do conceito de politização. Espera-se, assim, trazer contribuições para a agenda de pesquisa sobre política e burocracia.

Palavras-chave: Grupos de interesse. Burocracia. Indicações partidárias. Nomeações.

\section{Reflections on nominations to public office in Brazil: the experience of three secretariats from 2011 to 2018}

Abstract: This paper seeks to discuss the potential and challenges of studying the politicization of bureaucracy in Brazil. To this purpose, it presents a comprehensive literature review, exploratory data analysis, and three within-case studies of nominations in ministry agencies from 2011 to 2018 . The paper highlights the gaps in the literature about the role of interest groups in appointing nominees for high-level positions. As few studies explore the role of lobbying in decision-making about nominations to public offices, I turned to the specialized literature on pressure politics. The analysis of three national secretariats from different policy domains also provides novel theoretical insights in classifying and measuring the concept of politicization. I hope that these finding contribute to the study of politics and bureaucracy.

Keywords: Interest groups. Bureaucracy. Party nominations. Appointments.

\section{Reflexiones sobre nombramientos públicos en Brasil: la experien- cia de tres secretarias entre 2011 y 2018}

Resumen: El objetivo de este artículo es discutir los desafíos y potenciales investigaciones relacionadas a la burocracia en Brasil. Presenta una revisión integra de la literatura, análisis de datos y un estudio profundo de tres casos relacionados a la ocupación de puestos en organismos ministeriales entre los años 2011 y 2018. A su vez, destaca las carencias de la literatura con 
relación al papel de los grupos de interés en el proceso de designar los puestos de alta burocracia. Como son pocos los estudios que abordan el tema de los grupos de presión en las decisiones de nombramiento, busco la literatura especializada sobre política de presión. Además del análisis de las tres secretarías nacionales con diferentes dominios de políticas públicas, ofrece aportes teóricos para la clasificación y dimensionamiento del concepto de politización. Por lo tanto, espero contribuir con la investigación sobre política y burocracia.

Palabras clave: Grupos de interés. Burocracia. Indicaciones partidarias. Nombramientos.

Recebido em 27 de novembro de 2020

Aprovado em 31 de março de 2021 